\title{
CHILDREN, PROPAGANDA AND WAR, 1914-1918: AN EXPLORATION OF VISUAL ARCHIVES IN ENGLISH CITY
}

\author{
Infancia, propaganda y Gran Guerra 1914-1918: \\ una exploración de los archivos visuales en una ciudad inglesa
}

\section{Ian Grosvenor* and Siân Roberts ${ }^{\varphi}$}

Reception date: 04/05/2017 • Acceptation date: 30/08/2017

Abstract. Since 2014 there have been across Europe programmes of commemorative events to mark the Great War, 1914-18, and early amongst these events was an exhibition of photographs Paris 14-18, la guerre au quotidien at the Galerie des Bibliothéques de la Ville de Paris. The photographs were all taken by Charles Lansiaux, and record daily life in the city, from the recruitment and departure of French soldiers to victory celebrations in 1918. The exhibition importantly pointed to the fact that the Great War was the first conflict where the experiences of civilians were extensively visually documented. Further, as publicity for the exhibition noted: " $\mathrm{La}$ présence récurrente de groupes d'enfants dans ces photographies révèle la place nouvelle qui leur incombe, à l'aube du XXe siècle". Taking a lead from this exhibition this paper will investigate the wartime experiences of children in one English city, namely Birmingham, and how they were visually captured. In particular we will focus on documenting and analysing the connections between the representation of children at war, propaganda and the promotion of patriotism.

Keywords: First World War; Photograph; Birmingham; Children at war

Resumen. Desde 2014 ha habido a lo largo de Europa diversos programas conmemorativos de los acontecimientos que marcaron la Gran Guerra de 1914-1918. Uno de estos eventos fue la temprana exposición de fotografías Paris 14-18, la guerre au quotidien que tuvo lugar en la Galerie des Bibliothéques de París. Todas las fotografías habian sido tomadas por Charles Lansiaux, y versaban

\footnotetext{
* Dept. of Education and Social Justice. School of Education. University of Birmingham. Edgbaston. Birmingham B152TT. United Kingdom, i.d.grosvenor@bham.ac.uk

${ }^{\varphi}$ Dept. of Education and Social Justice. School of Education. University of Birmingham. Edgbaston. Birmingham B15 2TT. United Kingdom. s.roberts.2@bham.ac.uk
}

How to cite this article: Grosvenor, Ian and Siân Roberts. "Children, Propaganda and War, 19141918: An exploration of visual archives in English city». Historia y Memoria de la Educación 8 (2018): 307-345. 
sobre la vida cotidiana en la ciudad desde el reclutamiento y salida de los soldados franceses a las celebraciones de la victoria en 1918. La exposición señalaba, de manera importante, el hecho de que la Gran Guerra fue el primer conflicto en el que las experiencias de la población civil fueron visualmente documentadas de manera extensa. Además, como se indicaba en la publicidad de la exposición, "La presencia recurrente de grupos de niños en estas fotografías revela el nuevo lugar que les corresponde en los comienzos del siglo XX». Tomando como guía esta exposición, este artículo investigará las experiencias de los niños, durante el tiempo de guerra, en una ciudad inglesa, concretamente Birmingham, y cómo fueron visualmente captados. En particular, nos centraremos en documentar y analizar las conexiones entre la representación de la infancia en guerra, la propaganda y la promoción del patriotismo.

Palabras clave: Primera Guerra Mundial; Fotografía; Birmingham; Niños en la guerra

\section{INTRODUCTION}

In 2012 as part of the Cultural Olympiad the Library of Birmingham, Birmingham Museums and Art Gallery and the University of Birmingham collaborated on the exhibition Children's Lives. The exhibition used the archive and museum collections to document and explore the experiences of children in the city from the eighteenth century to present day. Part of the exhibition looked at children's lives during the First and Second World Wars. Since then we have both been active in working with a range of cultural partners in the city in developing a programme of activities to commemorate the city's involvement in the First World War. This in turn led to an exhibition in the Library of Birmingham, which focused on the day to day experiences of people on the home front in Birmingham and a successful bid to become one of the Arts and Humanities Research Council's First World War Engagement Centres. ${ }^{1}$ Childhood was a major theme in both initiatives. In particular, we were interested in exploring a series of interconnected questions about how war may have impacted on children. How did the experience of schooling change as a consequence

\footnotetext{
${ }^{1}$ The Voices of War and Peace Engagement Centre has received research council funding for the period 2014-2019 to work with community groups in the co-design and co-production of research relating to the legacy of the First World War. The Engagement Centre consists of a consortium of UK universities and cultural and heritage organisations led by the School of Education at the University of Birmingham. For more information, see www.voicesofwarandpeace.org.uk. The exhibition Voices of War: Birmingham People 1914-19 was held in the Library of Birmingham, September-December 2014, as part of the Centre's activities.
} 
of society's "war culture"? What role was ascribed to children and youth in the context of national wartime mobilization? How did schools and youth movements support the war effort? What were the experiences of refugee children that were displaced into a new urban environment? To what extent was there a moral panic about girls falling into sexual delinquency and increased illegitimacy and how far did the absence of male authority figures contribute to the rise of criminal children and delinquency both in the period of the war and in the decade immediately afterwards? How did the local state and voluntary organizations respond to the increase of orphans and single parenthood? ${ }^{2}$

Parallel to these local developments, programmes of commemorative activities began in the UK and in other parts of Europe. Amongst these events was an exhibition of photographs Paris 14-18, la guerre au quotidien at the Galerie des bibliothéques de la Ville de Paris. The photographs were all taken by Charles Lansiaux, and record daily life in the city from the recruitment and departure of French soldiers to victory celebrations in 1918. ${ }^{3}$ Walking through the exhibition and viewing the individual photographs was a useful reminder that not only was the First World War a conflict fought in front of the camera lens, it was also the first conflict where the experiences of civilians were extensively visually documented. Further, as publicity for the exhibition noted: "La présence récurrente de groupes d'enfants dans ces photographies révèle la place nouvelle qui leur incombe, à l'aube du $\mathrm{xx}^{\mathrm{e}}$ siècle". Children are "caught" watching military parades and adopting military poses, Boy Scouts march with along with soldiers, and children are photographed in family groups alongside their fathers in military uniform. Domestic images of children playing in parks, shopping and being entertained by street vendors are displayed next to photographs of child refugees and their families arriving from Belgium and children queuing in soup kitchens. A photograph of a hospitalized child injured in a bomb attack is followed by images of children looking at bomb damage on the street. Child newspaper sellers distribute news reports of events on the Western Front, while others sell patriotic medals

\footnotetext{
${ }^{2}$ For a recently published study of children during the First World War, see Rosie Kennedy, The Children's War: Britain, 1914-1918(Basingstoke: Palgrave Macmillan, 2014).

${ }^{3}$ The exhibition was open 15 January -15 June 2014. All of the images are reproduced in Marie-Brigitte Metteau (ed.) Paris 14-18, la guerre au quotidian. Photographies de Charles Lansiaux (Paris: Bibliotheques de la Ville de Paris, 2014).
} 
or are photographed collecting donations for war orphans and refugees. Children, their heads uncovered, observe the "spectacle" of a military funeral cortege while other children are photographed looking at artillery, sitting astride large canons and parading on Armistice Day. Collectively Lansiaux's photographs reveal the multiple contingencies which informed and controlled children's experiences of war time conditions. ${ }^{4}$

As a result of working with exhibitions as both curators and researchers, and seeing the visual history of childhood in wartime Paris, we decided that instead of following the traditional route of seeking answers to our questions about children's experiences of war in the written records housed in Birmingham's archives we decided to begin our search with the quintessential modern medium of the camera and documentary photographic practice. The photographic historian Darren Newbury has argued in his study of photography under the Apartheid regime in South Africa that "[photographs] are the starting point for inquiry rather than its end" ${ }^{5}$ and we were also interested in the possibility that taking a non-traditional approach might lead us in research directions which we might not otherwise have followed if we had begun with the written archive. At the outset we were conscious of the problematic "morass of contradiction, confusion and ambiguity" 6 around the status of the photograph as pure document -it is very evident that some of Lansiaux's images were, for example, staged "tableau" - but we were also sympathetic to Graham Clarke's contention that historic photographs are "literally records of a history otherwise unavailable to us", and that they

privilege us as they foreground events which we look at as if through a glass darkly. As documents, such images are windows into a world otherwise lost, and to that extent, are significantly and appropriately documentary photographs. ${ }^{7}$

\footnotetext{
${ }^{4}$ For a discussion of children's experience of the war in France, see StephaneAudoin-Rouzeau, "Children and primary schools of France, 1914-18" in State, society and mobilization in Europe, during the First World War, ed. John Horne (Cambridge: Cambridge University Press, 1997), 39-52; and Mona L. Siegel, The Moral Disarmament of France. Education, Pacifism and Patriotism, 1914-1940 (Cambridge: Cambridge University Press, 2004).

${ }^{5}$ Darren Newbury, Defiant Images: Photography and Apartheid South Africa (Pretoria: University of South Africa Press, 2009), 4.

${ }^{6}$ Susan Moeller, Shooting War: Photography and the American Experience of Combat (New York: Basic Books, 1990).

${ }^{7}$ Graham Clarke, The Photograph (Oxford: Oxford University Press, 1997), 146.
} 
The use of photographs in historical and social research has its own literature. Becker, for example, advised the researcher to focus on "questions" a photograph "might be answering", which could be very different to what the photographer actually intended, and to then look for corroborating evidence. ${ }^{8}$ Banks advocated the use of three sets of questions:

(i) what is the image of, what is its content? (ii) who took it or made it, when and why? And (iii) how do other people come to have it, how do they read it, what do they do with it? ${ }^{9}$

More recently, Tinkler has suggested a five steps approach to using photographs: identifying basic details (place and time), scrutinizing images for content, considering material evidence, doing contextual research, and reflecting on meaning. ${ }^{10}$ Scott unlike Becker, Banks and Tinkler did not distinguish between photographs and written sources and identified four lines of enquiry: authenticity, credibility, representativeness and meaning. ${ }^{11}$ This approach is mirrored by Jordanova who does not isolate photography from other visual media and promotes treating visual materials with the same rigour as any other source asking basic questions about provenance, audience, and the context of both production and reception. ${ }^{12}$ There is clearly significant overlap within these different methods of engaging critically with photographs as historical evidence. While our primary concern was with the documentary content of photographs and the questions that this content raised for our concern with children, it was important that we remained alert to the issues around authenticity, audience, production and reception. ${ }^{13}$

\footnotetext{
${ }^{8}$ Howard Becker, "Do photographs tell the truth?" in Qualitative and Quantitative Methods in Evaluation Research, eds. T. Cook and C. Reichardt (London: Sage, 1979), 101.

${ }^{9}$ M. Banks, "Visual Methods in Social Research", Social Research Update, 11 (1995): 7.

${ }^{10}$ Penny Tinkler, Using Photographs in Social and Historical Research (London: Sage, 2013), 19-32.

${ }^{11}$ John Scott, A Matter of Record: Documentary Sources in Social Research (London: Polity, 1990), 19-35.

${ }^{12}$ Ludmilla Jordanova, "Approaching Visual Methodologies", in Research Methods for History, eds. Simon, Gunn and Lucy Faire (Edinburgh: Edinburgh University Press, 2011), 30.

${ }^{13}$ See also Ian Grosvenor, "On Visualising Past Classrooms", in Silences and Images. The Social History of the Classroom, eds. Ian Grosvenor, Martin Lawn and Kate Rousmaniere (New York: Peter Lang, 1999), 83-104; Ludmilla Jordanova, The Look of the Past. Visual and Material Evidence in Historical Practice (Cambridge: Cambridge University Press, 2012); Ian Grosvenor and Kate Rousmaniere, "El uso de materiales visuales en la investigación histórico-educativa", Revista Mexicana de Historia de la Educación, IV, no. 8 (2016): 231-53.
} 


\section{BIRMINGHAM: VISUALISING THE CITY AT WAR}

Unlike Paris, but perhaps more in line with other urban photography collections, we found no single extensive collection of First World War photographs in the Birmingham archive. Instead, the many images of the War and its effects are dispersed across a large number of collections. We prioritized the search in collections, which we knew from previous experience to be likely sources of images of children - the archives of families, charitable institutions and war related propaganda. We also targeted certain local newspapers, which we knew began to use images heavily in this period, predominantly the most "tabloid" end of the local press in the form of the Birmingham Illustrated Weekly Mercury and to a lesser extent the Birmingham Gazette. Taking a sample year initially we discovered a wealth of war imagery reproduced in the Birmingham Illustrated Weekly Mercury in particular, and broadened the time frame to the whole of the war period. In doing so, we recognized that the nature of the newspaper coverage is weighted towards positive images intended to bolster support for the war effort, a point recognized by the war-time Lord Mayor of Birmingham, Sir David Brooks, when he wrote that "Tribute should also be paid to the patriotic attitude adopted by the local newspapers throughout the war", and drew attention to their role in "educating public opinion" in supporting military recruitment and financial campaigns in particular. ${ }^{14}$ The original photographs used by the newspapers are presumed lost. Not surprisingly, collectively their documenting of a city at war and in particular the experiences of children mirrors those produced by Lansiaux. In what follows we look at ten photographs from the many identified in the Birmingham archive and document the issues and questions that they prompted both individually and collectively.

Brooks' comments quoted above reflect the fact that the city in which the photographs were taken was a city fully mobilized for war. As one of England major industrial centres, Birmingham's manufacturing base was turned over en masse to the war effort, and to the making of armaments and munitions in particular. Local factories increased their output and their workforce, and the employees of one local factory, Austin Works

\footnotetext{
${ }^{14}$ Foreword to Reginald H. Brazier and Ernest Sanford, Birmingham and the Great War 1914-1919 (Birmingham: Cornish Brothers, 1921), vii.
} 
in Longbridge, for example, grew from 2,800 in 1914 to over 20,000 by 1918. The city's population grew exponentially as male and female workers, soldiers, medical personnel, the wounded, and refugees poured in from other parts of Britain and beyond. However, the city was also home to a small but vocal opposition to the war led by members of the Religious Society of Friends (also known as Quakers) and the political left, including members of the Independent Labour Party, among others. This opposition was manifested by individual Conscientious Objectors who refused to take up arms and were duly prosecuted, and by collective public demonstrations such as the women's peace marches held in the city at various intervals. ${ }^{15}$

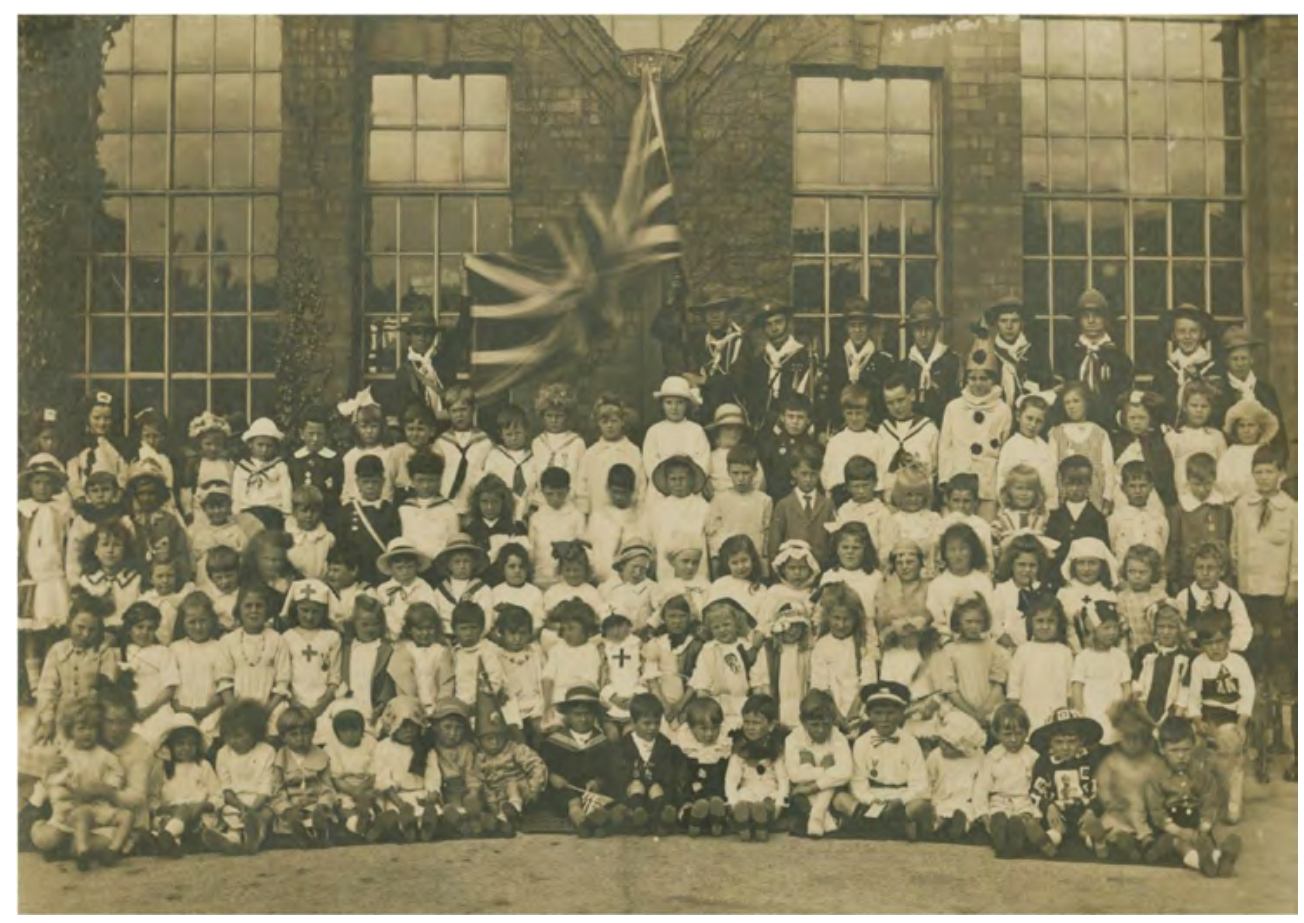

Figure 1: Victory celebrations at Bordesley Green School, Birmingham, 1918, MS 1645/14.

Reproduced with the permission of the Library of Birmingham.

\footnotetext{
${ }^{15}$ For more on Birmingham during the First World War, see Siân Roberts, Birmingham: Remembering 1914-18 (Stroud: The History Press, 2014).
} 
Turning specifically to the photographs, our first image is from the end of the war (figure 1). It is an example of the genre of the school photograph that became increasingly commonplace at the end of the nineteenth century: the whole school/class group portrait, and the familiar architecture of Birmingham school design, in this case at Bordesley Green, can be clearly seen behind the group. Children, mainly of infant and junior age, have been organized in rows with the youngest sitting at the front. Two rows of older children are standing on benches that are hidden from view and behind them are much older boys who are in their scout uniforms. All of the other children are wearing some form of costume rather than their ordinary clothes including eleven boys wearing sailor suits, five girls dressed as nurses, three boys are wearing "Pierrot" outfits, a popular costume associated with the Edwardian music hall and seaside entertainment, and one boy is dressed as a wizard. At first sight, there appears to be an absence of adults, but closer scrutiny reveals the head of a man almost in hiding behind the back row and the leg, shoulder and part of the hat of a figure outside of the frame who is attached to the scouts, occupying the space usually of an adult in school photographs.

Looking at the photograph the eye is immediately drawn to the centrality of the Union Jack flag in the photograph's composition which, despite being held by two boy scouts, is caught moving. A boy wearing a Union Jack is also waving a second flag. Behind him another boy is wearing a sort of Union Jack cravat and a girl in the row behind him has a shawl or Union Jack dress. Several children are wearing medals, including one of the nurses, while others wear rosettes. At the front a small boy wears a dark hat and outfit with different symbols attached and on his front is an image of King George V. Along from him, and placed directly in line with the billowing Union Jack flag, is a small boy in a sailor suit who is holding another flag, but not the Union Jack - it is the Stars and Stripes of America.

Only a few of the children can be described as looking happy and indeed many look totally bemused or even bored with what is going on. Given the length of time, it would have taken to organize them [and their costumes?] this apparent lack of enthusiasm for the experience is not surprising. All of these children were born before the outbreak of war 
and therefore they would have all experienced in some way its impact on their lives. Their understanding of this experience would naturally be filtered by age and circumstance. But what would they have taken and remembered from this "celebratory" moment of which they are a part; a moment saturated with the symbols of patriotism and nation?. What would they have drawn upon to make sense of it? These are questions which we kept returning to as we explored through the images the impact of the culture of war on Birmingham children.

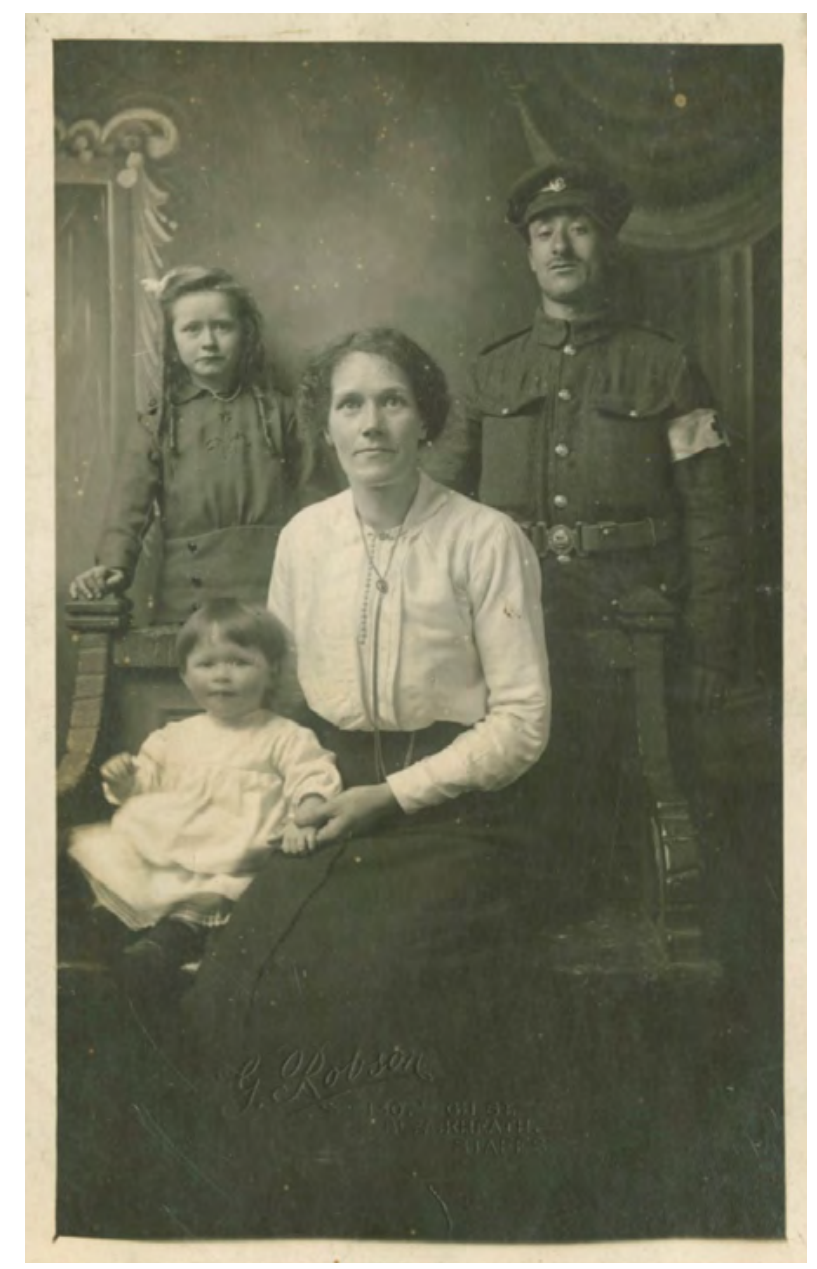

Figure 2: Abednego Parsons and family, 1915, MS 4616/1. Reproduced with the permission of the Library of Birmingham. 


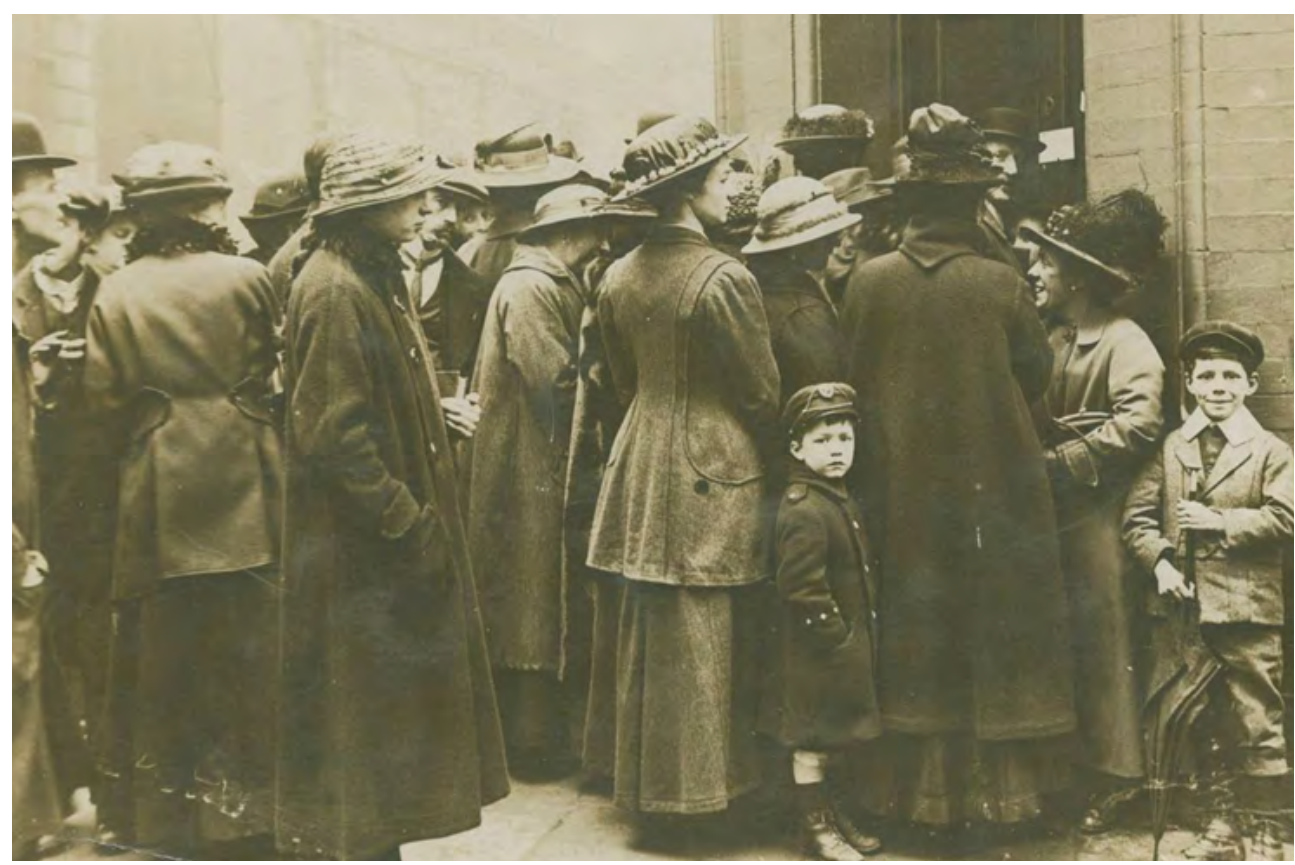

Figure 3: A food queue in Birmingham, 1917, MS 4616/1.

Reproduced with the permission of the Library of Birmingham.

All photographs generate questions and because photographs are "randomly inclusive" carrying an excess of information any individual photograph has more than one story to tell ${ }^{16}$. This plurality of narratives can be expanded by juxtaposing one image with others, which potentially open up new lines of enquiry in the archive. Here we take four separate images. The first is of the Parsons family of Halesowen, ${ }^{17}$ 1915, showing Abednego Parsons, his wife Fanny, and their daughters Sarah and Norah (figure 2). The second is of a Birmingham food queue in 1917 (figure 3). The third is from an article in the Birmingham Illustrated Weekly Mercury in 1918 about photographs 'found' on the battlefields (figure 4). The last image is from 1920 and is of children on a Birmingham Co-operative Society float at the May Day parade under the banner of "War Made us Fatherless" (figure 5).

\footnotetext{
${ }^{16}$ Elizabeth Edwards, "Entangled Documents: Visualised Histories", in Susan Meiselas: In History, ed. K. Lubben (Gottingen: Steidl, 2008) 333.

${ }^{17}$ Halesowen is part of the Greater Birmingham area.
} 


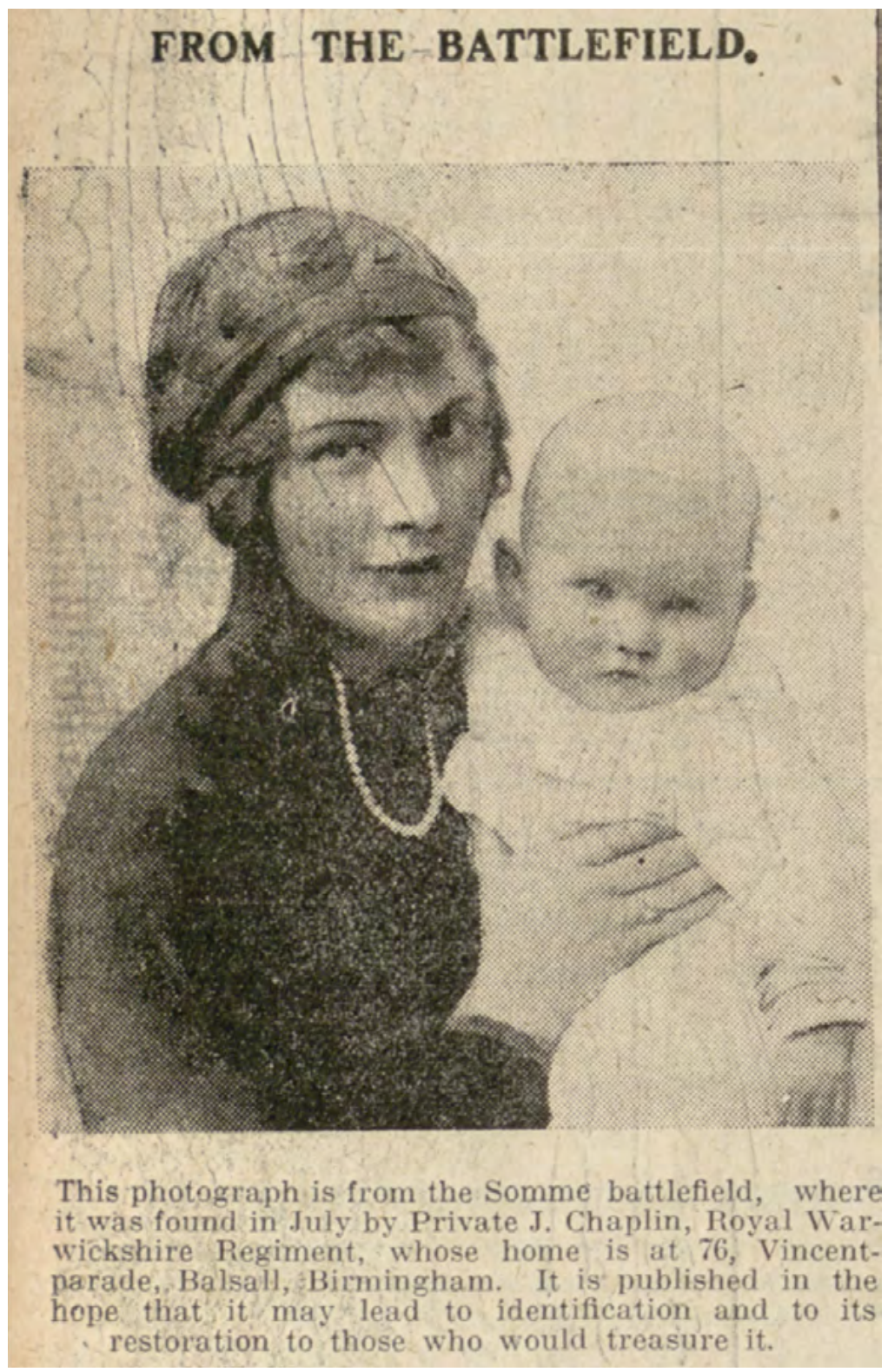

Figure 4: 'From the Battlefield', The Birmingham Illustrated Weekly Mercury, 7 October 1916, back page. Reproduced with the permission of the Library of Birmingham. 


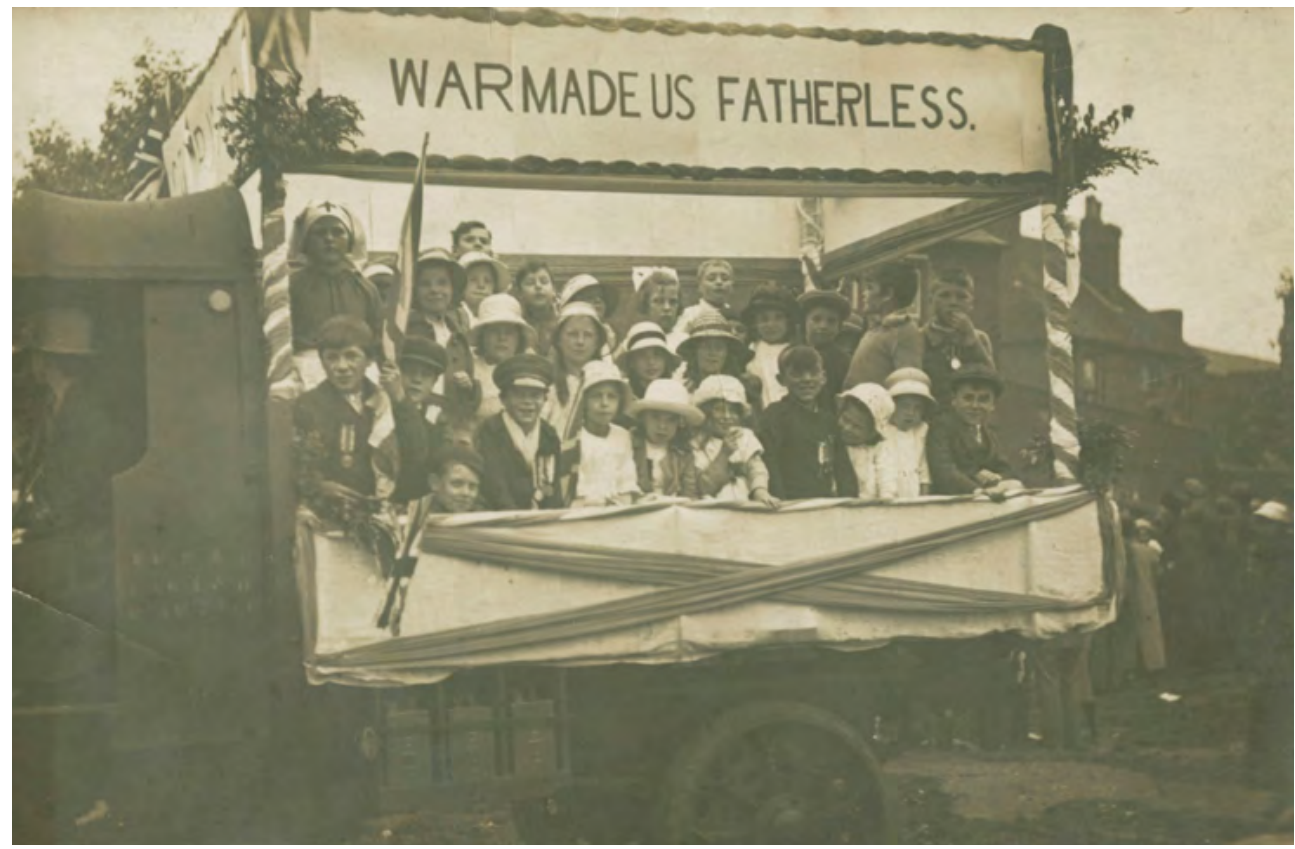

Figure 5: Children on a Birmingham Co-operative Society float at the May Day parade, 1920, MS 4616/1. Reproduced with the permission of the Library of Birmingham.

Abednego was a Private in the Royal Army Medical Corps and served in France. He survived and returned home at the end of the war. The family is shown in a conventional studio pose with the father standing behind the mother. Elizabeth Edwards has described such photographs as "little theatres of self" as in the anonymity of the studio they project an ideal, both personal and collective, capturing a moment when the "mythic and the idealised self, in "Sunday best" was performed" and made visible "the abstract norms, values and feelings that surround social life". ${ }^{18}$ It was also through such moments she also argues that children learned the conventions and traditions of photography, "what it meant to have one's photograph taken". ${ }^{19}$ In many working class households such photographs represented in the

\footnotetext{
${ }^{18}$ Elizabeth Edwards, “"Little Theatres of Self". Thinking about the Social” in James Fenton, Elizabeth Edwards and Tom Phillips, We are the People. Postcards from the Collection of Tom Phillips (London: National Portrait Gallery, 2004), 29-31.

${ }^{19}$ Edwards, “"Little Theatres of Self”. Thinking about the Social”, 32.
} 
first half of the $20^{\text {th }}$ century the only surviving document of family history. ${ }^{20}$ The image captures a likeness of a father and a husband that could be kept on the mantelpiece to be treasured by those who are faced with an impending moment of departure and with no knowledge of the moment of return.

Abednego went with the Royal Army Medical Corps to France. What did Sarah and Norah feel at being separated from their father and not knowing if or when he would return? What difficulties did Fanny face with her husband's absence? Keeping in touch through letters and parcels connected families with absent fathers. Holding a letter, as Santanu Das has argued, physically and emotionally connected the writer with the recipient of the a letter, ${ }^{21}$ but gaps in correspondence and the uncertainty and anxiety associated with waiting to hear from loved ones inevitably, as Michael Roper has documented, had an emotional impact on family life and relationships. ${ }^{22}$

Materially, we know that the War Office introduced a system of remittances which allowed soldiers to have an element of their pay sent directly to their families and wives and dependents became entitled to a Separation Allowance, but prior to these actions many families suffered significant financial hardship with income significantly reduced by men leaving for war, unemployment and economic uncertainty. In the early months of the war school log books from Birmingham provide valuable information on these hardships. For example, the Head Teacher of Dartmouth Street Boys School recorded at the end of August that there was "much distress in this district" as "about 40 fathers and 60 brothers of our boys have been called up" and the number of free breakfasts had increased from 30 to 70 . The following week saw the figure for free breakfasts double to 150, a week later it was 200 and by the end of September the school was providing 300 free breakfasts. ${ }^{23}$

\footnotetext{
${ }^{20}$ Audry Linkman and Caroline Warhurst, Family Albums (Manchester: Manchester Studies, 1982), 2.

${ }^{21}$ Santanu Das, Touch and Intimacy in First World War Literature (Cambridge: Cambridge University Press, 2005), 13.

${ }^{22}$ Michael Roper, The Secret Battle. Emotional Survival in the Great War (Manchester: Manchester University Press, 2009), 86-93.

${ }^{23}$ Library of Birmingham, S 56/2/2, Dartmouth Street Boys School Log Book, August-September, 1914.
} 
Such hardships were gradually reduced in Birmingham as family incomes increased through rising wages and earnings from overtime, as the war economy brought women into the munitions industry and other, previous male dominated roles. As Jerry White notes, "all families, especially those with children over the school-leaving age, could expect to generate a household income from many sources, with each often earning well and regularly". ${ }^{24}$ Nevertheless, even higher wages could not fully offset the problems of food shortages which the war brought. Securing an adequate supply of food was a problem throughout the war but from 1917 it became a serious issue. Queues outside food shops, as in the photograph, became a regular sight, and Birmingham Schools' Medical Officer complained that children were being kept off school to wait in food queues. ${ }^{25}$ In this image the continuing 'novelty' of the camera on the street is readily apparent with two children and two adults looking directly at the photographer. The adults, predominantly women, are pressed together waiting for the shop to open, they are not the poorest of Birmingham's population and generally appear relaxed. The one boy is dressed in a military style overcoat and a cap with insignia. However, in the poorest parts of the city food shortages hit hard as the Head Teacher of Dartmouth Street Boys noted in February 1917: "Attendance lowest for some time [...] The weather [and] Food and fuel are scarce and there are many scholars ill". ${ }^{26}$

Thrift became a way of life in the city and "Economy in Waste" leaflets were distributed through schools and other organisations. ${ }^{27}$ Old tin cans were collected and recycled, householders were asked to gather waste paper, and even offal from slaughterhouses was repurposed as food for pigs and poultry and as fertiliser. ${ }^{28}$ There was an increased emphasis on growing more food particularly as 1917 saw a serious shortage of potatoes. The City's Parks Department made more allotment plots available and supplied seeds at reduced prices. By the end of the war about 1,800 acres of land in the city were covered by

\footnotetext{
${ }^{24}$ Jerry White, Zeppelin Nights. London in the First World War (London: Bodley Head, 2014), 226.

${ }^{25}$ Library of Birmingham, Annual Report of the School Medical Officer, 1917, 4.

${ }^{26}$ Library of Birmingham, S 56/2/2, Dartmouth Street Boys School Log Book, 9 February 1917.

${ }^{27}$ Library of Birmingham, S 48/1/1, City Road School Log Book, June 1917; for a copy of the leaflet distributed see Library of Birmingham, MS 4383.

${ }^{28}$ Library of Birmingham, MS 4383; Brazier and Sandford, Birmingham and the Great War, 207.
} 
allotments. ${ }^{29}$ In August 1917, the Government's Food Controller requested all local authorities to appoint food control committees and in Birmingham a registration scheme for all outlets selling sugar and ration cards for sugar were introduced in September 1917. Butter, margarine, tea and bacon were also in short supply. A general rationing scheme was tried in Birmingham as an experiment and from $12^{\text {th }}$ December every house in the city received a ration card for tea, sugar, butter and margarine. A similar card was introduced to ration meat. The Birmingham trial later became the basis for the rationing scheme that was introduced nationwide in July 1918. Roper has documented how such hardships on the Home Front made "family relationships brittle". ${ }^{30}$

Towards the end of the war the Birmingham Illustrated Weekly Mercury newspaper ran a series of appeals asking for information about family photographs found abandoned on the battlefield. These are images which for those left behind visually represented the possibility of loss, and if not proof of loss, they certainly spoke of uncertainty. The contingency of death was particularly difficult for those who remained at home. As Mary MacLeod Moore wrote in the Sunday Times: "Killed" is final; "Wounded" means hope and possibilities; "Prisoner of war" implies a reunion in the glad time when peace comes again to a stricken work; but "Missing" is terrible. In that one word the soldier's friends see him swallowed up "behind a cloud through which pierces no ray of light". ${ }^{11}$ For a child to turn a page in a newspaper and suddenly to find themselves and that of a missing father or sibling returning their gaze would have been deeply distressing, and if the photograph in the newspaper and that on the mantelpiece was all that remained the missing body made it difficult to grieve properly.

For some women the loss of a husband and father to her children was too great a burden and the children ended up in care. The father of the Cook children was killed in action in 1915 and the mother turned to alcohol, spending army pay on drink and was drunk for a fortnight. Care for the children was transferred to Middlemore Homes

\footnotetext{
${ }^{29}$ Brazier and Sandford, Birmingham and the Great War, 332.

${ }^{30}$ Roper, The Secret Battle, 185.

${ }^{31}$ Mary MacLeod Moore, “Missing”, Sunday Times, 8 July, 1917.
} 
and the family's story was reported in the press under the headline "Sad Story told at the Police Court". ${ }^{32}$ The case files of Middlemore Homes are full of stories of children being put at risk of neglect due the war. It is also clear from these files that children were emotionally damaged due to loss. ${ }^{33}$ Younger children would have had only the briefest of memories of fathers and siblings, but they were expected to engage in the cult of remembrance. As Catherine Rollet has so perceptively written:

Death in wartime formed a conclusive reference point for their developing identity [...] With time, direct memory of the father came to be merged with or submerged beneath the memory constructed by the family and by the nation. A significant obligation imposed itself on everyone: the living had a debt they owed the dead and the children had to play an active part in this duty of remembrance. ${ }^{34}$

The "fatherless" children in the 1920 May Day photograph perfectly project this active role in the duty of remembrance. The act of loss publically defined these thirty or more children. Their fathers died for the flag and the medals worn by the boys materially declare their acts of sacrifice. At the same time, the banner "WAR MADE US FATHERLESS" might also be read as implicitly carrying another message that war "just or unjust, is a war against the child". The children were part of the May Day procession, a political event organized by the local labour movement and attended by trade unions and a campaigning group for former soldiers, the National Union of Ex-Servicemen, among others and which concluded with a political rally. ${ }^{35}$

\footnotetext{
${ }^{32}$ Library of Birmingham, MS 517/A/8/1/4, 23 September 1915. The Middlemore Homes were children's emigration homes for boys and girls originally founded in 1872 to emigrate poor children, often forcibly removed from their parents, to Canada and later Australia. During the First World War, the Homes agreed to retain those children of soldiers, who were placed temporarily in the Homes, in Birmingham rather than send them abroad in case the father returned following the end of the conflict.

${ }^{33}$ Library of Birmingham, MS 517/A/8/1/4, 18 August 1915.

${ }^{34}$ Catherine Rollet, "The home and family life", in Capital Cities at War. Paris, London, Berlin 1914-1919. Volume 2: A Cultural History, eds. J. Winter and Jean Louis Robert (Cambridge: Cambridge University Press, 2007), 347. See also, Sandy Callister, "Picturing Loss: Family, Photographs and the Great War", The Round Table. The Commonwealth Journal of International Affairs, 96, no. 393 (2007): 663-678.
}

${ }^{35}$ The Birmingham Post, 3 May 1920. 
We know that Abednego survived the war, but what was the impact of his return on his children? Roper has drawn attention to different interpretations amongst historians looking at the emotional impact of war on British soldiers with one group arguing that the "encounter with violence undid the civilizing process" while another has pointed to a status of alienation and an "estrangement from home". Both elements, he argues, were evident amongst soldiers and defined their behavior when they returned home. Certainly, many fathers returned with ill health, both physical and mental, and anger at what had happened to them and a level of dependency which further pressurized family relationships. ${ }^{36}$ Sometimes this pressure was too much as the Middlemore case records again demonstrate. When their father returned injured from the war and was in a convalescent home with paralysis of the face, the Benbow children were placed in care because of maternal neglect due to drunkenness. ${ }^{37}$ Finally, an interesting by-product of soldiers "returning from the front" as reported by the School Medical Officer in 1916 and again at the end of the war was the outbreak of a scabies epidemic amongst children. $^{38}$

\footnotetext{
${ }^{36}$ Roper, The Secret Battle, 286-90.

${ }^{37}$ Library of Birmingham, MS 517/A/8/1/4, 10 September 1915.

${ }^{38}$ Library of Birmingham, Annual Report of the School Medical Officer, 1916, 10; 1918, 9.
} 


\section{INSTITUTIONAL CHILDHOODS AT WAR}
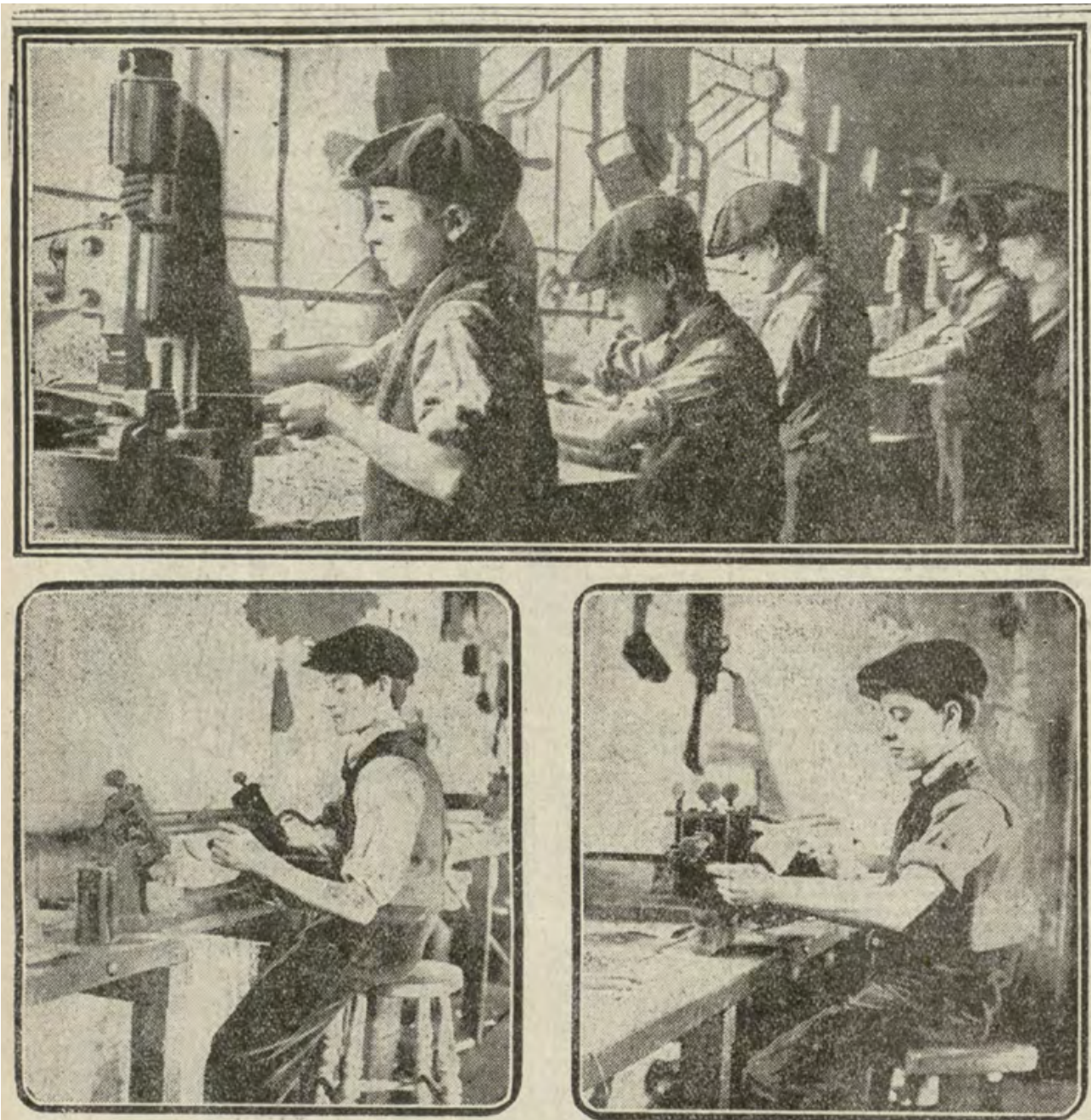

Government work being done at a local factory by youthful helners from the Norton Boys' Home, Saltley. The pictures sho (top) Boys at work on the presscs, ; (bottom, left) Boy rolling fuee tapes; (right) rolling tin lida for fuse boxes.

Figure 6: Children making munitions, The Birmingham Illustrated Weekly, 14 August 1915, p. 6. Reproduced with the permission of the Library of Birmingham.

A newspaper photograph of boys working for the war effort prompted a new line of inquiry: the role of delinquent children in the war (figure 6).The boys were from Norton, formerly known as Saltley Reformatory, 
which was essentially a prison for young offenders. ${ }^{39}$ Boys were admitted between the ages of about nine and 17 their lives were strictly regulated. Activities were timetabled for each day between waking up at $6 \mathrm{am}$ and going to bed at $10 \mathrm{pm}$. They were educated and trained in various trades, including shoemaking, gardening, tailoring and farming. The contribution to the war effort was substantial as the School Superintendent detailed in 1916, the boys had produced in the workshops:

thousands of articles of equipment have been either wholly or partly made up —namely, 5,000 dispatch riders' kit covers, 2,500 bandoliers, 2,500 buckle straps, 1,000 military mail bags, 3,400 ammunition pouches, 1,579 water bottle carriers, 925 flag-signaller cases. ${ }^{40}$

At this time, in addition to working on the farm or in the workshops, 20 other boys were working in munitions factories.

The Annual Reports give a figure each year for the number of old boys wounded or killed in action, and a common thread through the reports is a discourse about masculinity and war; a discourse that connected the "true spirit of manhood [...] the high [...] tone of courage and endurance" displayed by former boys on the Western Front with the values "fostered by the school" and still being "inculcated". ${ }^{41}$ A selection of letters from old boys which reflect this discourse but also give details of life at the Front, being stationed in India or convalescing in hospital, were printed in the reports in every year except 1918 when there was a paper shortage. This practice of including the letters of "old boys" in annual reports was very common among educational and charitable institutions in Birmingham during the war, and a similar trend can be seen in the employees' magazines of the city's industrial firms and manufacturers. The letters offer further evidence of the importance of 'keeping in touch' as the following extracts from 1915 demonstrate:

\footnotetext{
${ }^{39}$ Saltley Reformatory opened in the mid nineteenth century. It was renamed Norton Training School from 1908, and Norton Approved School from 1933. However, despite the changes in name, and some evolution in practice, its primary function, which was to incarcerate, train and "reform" young offenders, remained the same until the late twentieth century.

${ }^{40}$ Library of Birmingham, L43.94, Birmingham Reformatory 63rd Annual Report, 1916, 10.

${ }^{41}$ Library of Birmingham, L43.94, Birmingham Reformatory 62nd Annual Report, 1915, 7.
} 
I received your most welcome letter this evening and you cannot realise how pleased I was when I opened it [...];

Many thanks for forwarding the "Schools Gazette". They are very interesting and I read through during my spare time out of the trenches;

[ A letter ] acts an incentive, [...] [it] is a strong connecting link with the boys of the old school, and through this medium we, who are in the trenches, can vividly and happily recall chums of bygone days. ${ }^{42}$

The old boys were responding to letters sent by both staff and inmates. One letter is particularly interesting regarding the boys' participation in the war effort:

Dear Davey [... ]it is very nice to receive letters from friends, it cheers one up such a lot in the trenches [...] I was glad to hear the band is doing such good work in trying to recruit as much as possible. Always remember, although you are not out here fighting, you are all taking your part in this great War by trying to encourage others to enlist, and help to defend the country's honour. $^{43}$

There is an allusion in the 1917 report to the increase in delinquency being experienced in cities ${ }^{44}$ and as a consequence pressure being put on the reformatory schools "to provide accommodation for cases committed to their charge". At Norton nearly twice as many boys were admitted in 1916-1917 compared to the previous year and boys were passing through the school too quickly, the training was too short and this was "adverse to the boy's welfare". ${ }^{45}$ A sense of unease is evident in the Superintendent's report in June for 1918: "Even in these times of unrest it is marked how well the general conduct of the boys has been maintained". ${ }^{46}$

\footnotetext{
${ }^{42}$ Library of Birmingham, L43.94, Birmingham Reformatory 62nd Annual Report, 1915, 15-18.

${ }^{43}$ Library of Birmingham, L43.94, Birmingham Reformatory 62ndAnnual Report, 1915, Letter from Bandsman Odell 1st Warwickshire Regiment, 18.

${ }^{44}$ See Victor Bailey, Delinquency and citizenship: Reclaiming the young offender, 1914-1948 (Oxford: Clarendon Press, 1987).

${ }^{45}$ Library of Birmingham, L43.94, Birmingham Reformatory 64th Annual Report, 1917, 7.

${ }^{46}$ Library of Birmingham, L43.94, Birmingham Reformatory 64th Annual Report, 1917, 7.
} 
The reported highlight of 1917 was the formation of a Cadet Corp affiliated to the $6^{\text {th }}$ Royal Warwickshire Regiment and by 1918 it had become "the centre of the Home" and had, according to HMI Norris, a "marked effect on the bearing and smartness of the boys and no doubt accounts for the prevailing alertness of expression". The apparent popularity of the Corps with the boys is possibly a reflection of a longstanding attraction to military "involvement" amongst young males in Birmingham, with one in every 11 males aged between 17 and 25 years being a member of the Territorials in 1911 and a further 1 in 25 was a member of the Army Special Reserve. ${ }^{47}$ Throughout 1918-1919 the Corp had participated "in every public event [...] including the visit to the City of [...] the King and Queen, Presentations of War Honours [...] and the raising of War Funds", but school based work and industrial training were "handicapped" by staff shortages due to war service.

An further indication of the centrality of the Corp for the Home is the shift in the focus of the photographs included in them from sporting teams to images of the Corp, including in 1921 photographs of a parade at the Arc de Triomphe and band playing at Verdun as part of the Corps ovisiting battlefields and places connected with the great War". ${ }^{48}$

The next two photographs are associated with the field of battle. Both come from a commemorative album for the city's "Tank Bank Week" which was held $31^{\text {st }}$ December 1917- 5 January 1918 to raise money for the war effort. This week, held in Birmingham as the last year of the war opened, was an effort to raise additional funds for the war and to boost public morale. A tank was placed outside the Town Hall in the city's main civic square to draw in the crowds, playing to the public's desire to see this new technology of the war. A civic competitive spirit came into play and Birmingham was keen to outdo other cities that had already held similar events, and in particular to collect more money than Manchester and Liverpool which had raised $£ 4,450,020$ and $£ 2,060,512$ respectively. A huge board was erected at the side of the Town Hall on which the daily totals were displayed with the message "Birmingham Must Win", and a variety of events and speeches were held in the square every day. The

\footnotetext{
${ }^{47}$ Joanna Bourke, Dismembering the Male. Men's Bodies, Britain and the Great War (London: Reaktion Books, 1996), 182.

${ }^{48}$ Library of Birmingham, L43.94, Birmingham Reformatory 68th Annual Report, 1921, 7.
} 
grand total in Birmingham once postal deposits had been included in the count was $£ 6,703,439$. The first image, clearly posed for maximum impact, is of a small boy dressed in a sailor's outfit returning the salute of an army officer while handing his contribution to another soldier half hidden inside the tank that gave the week its name (figure 7). The second image from the album, which appears to have been taken at an event during the week from the tank or a nearby platform, is of a large crowd assembled in the civic square and all looking at the photographer as if wishing to see into the future. Two Union Jack flags hang above their heads and positioned at the front of the photograph are three Boy Scouts (figure 8$).{ }^{49}$

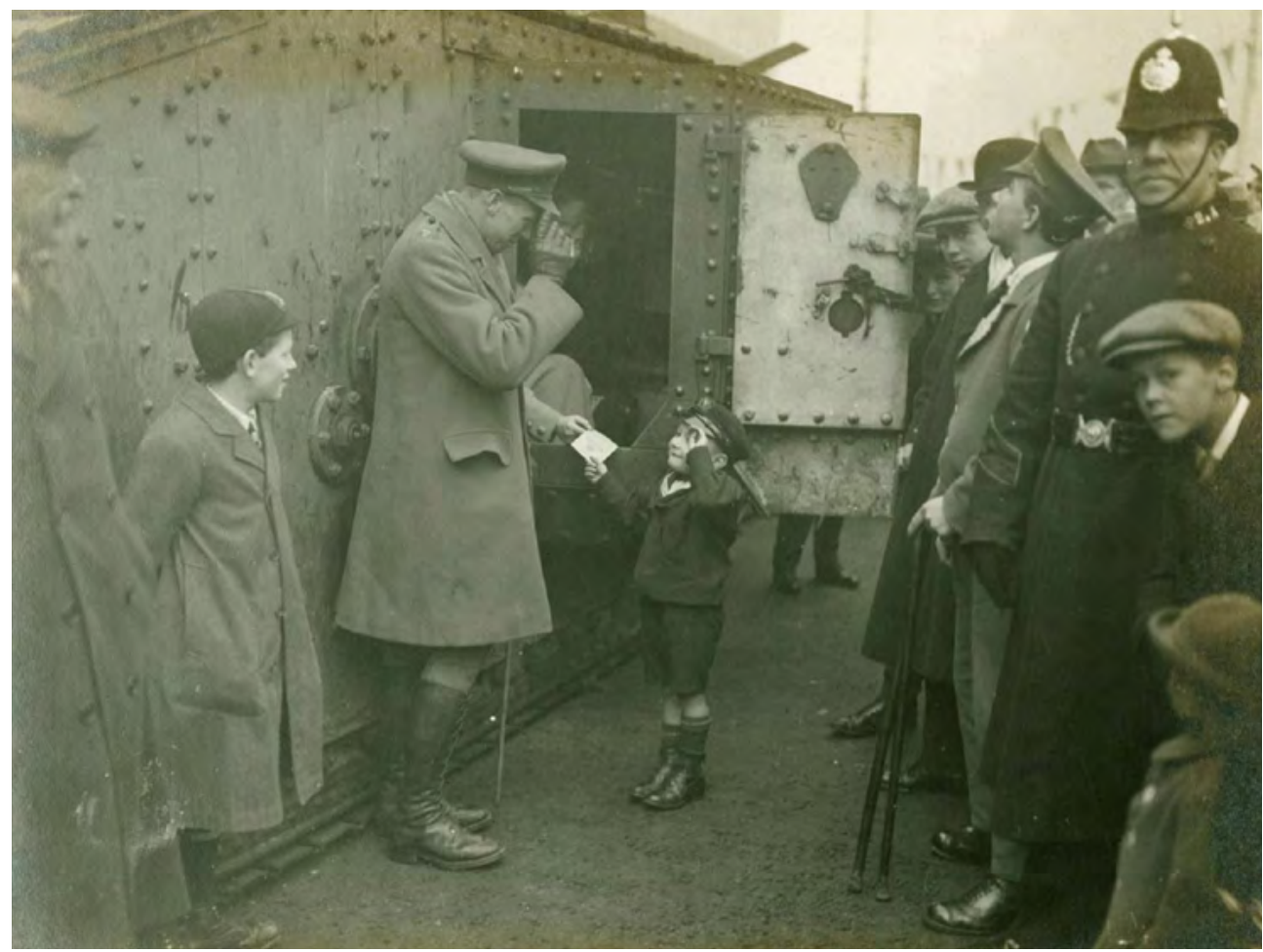

Figure 7: Child saluting, Birmingham Tank Bank Album, 1918, LF 75.7/531718. Reproduced with the permission of the Library of Birmingham.

\footnotetext{
${ }^{49}$ Library of Birmingham, LF75.7, Tank Bank Week Commemorative Album, 1918.
} 


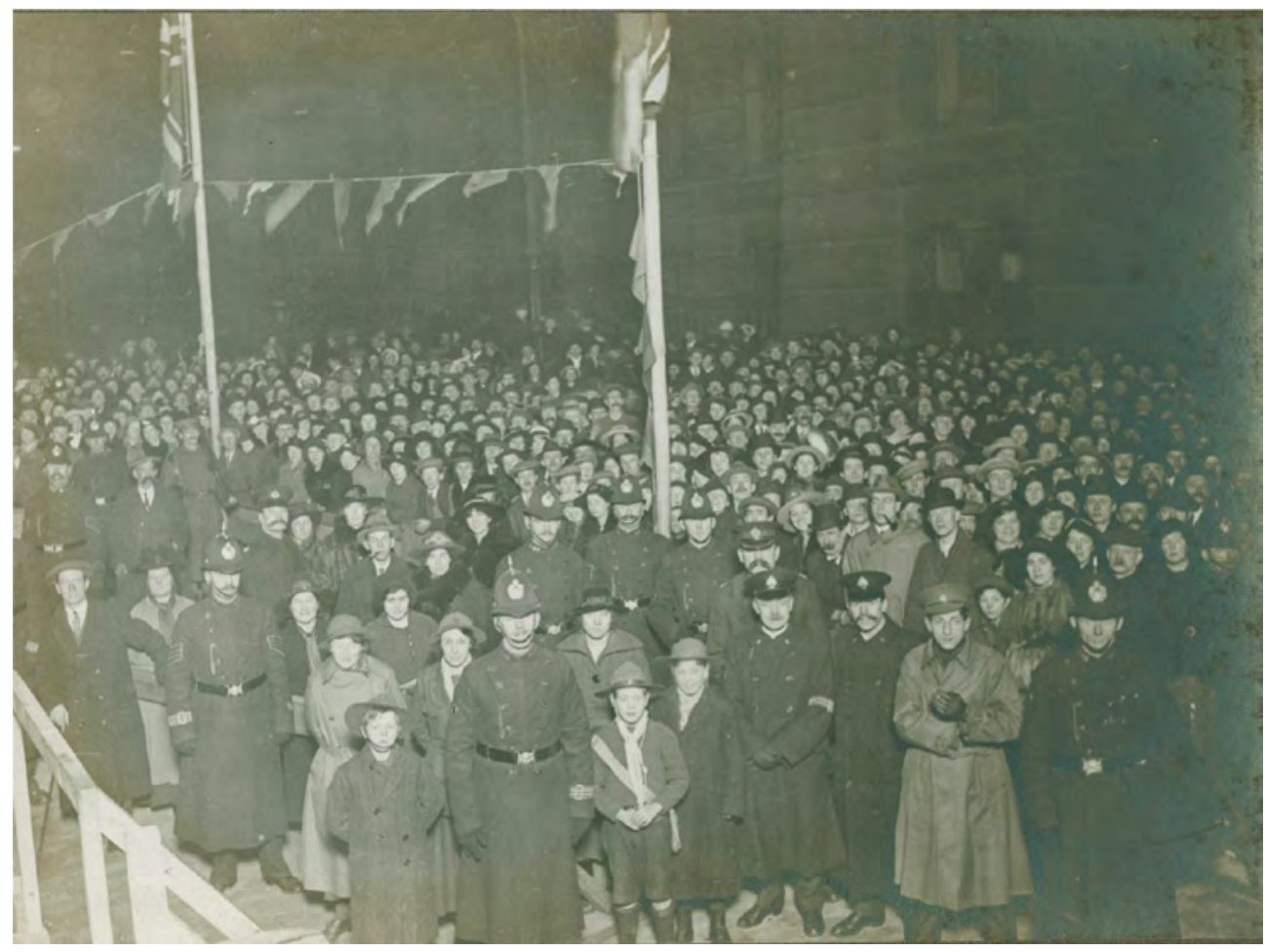

Figure 8: Crowd scene, Birmingham Tank Bank Album, 1918, LF 75.7/531718. Reproduced with the permission of the Library of Birmingham.

In this second photograph the central position of the scouts in the photograph is reflective of the organization's mobilization in the war effort. ${ }^{50}$ Early in the war "Birmingham's Scout Army", as the Weekly Mercury put it, made itself useful in recruitment campaigns. Another photograph in the Birmingham Gazette on 27 ${ }^{\text {th }}$ August 1914 showed a Scout holding up a placard emblazoned with the challenge "I am too young to enlist. You are not". Later Scouts worked as bell-boys on trams, built huts for soldiers, worked for the Public Works Committee whitening street kerbs and lamp-posts in parks and helped with air raid precautions. Rollet has argued that "a whole "war culture" aimed at children" was created so that "they too could share in the national effort" ${ }^{51}$ It is certainly the case

\footnotetext{
${ }^{50}$ See, Kennedy, The Children's War, chapter 4, for a discussion of children in uniform.

${ }^{51}$ Rollet, "The home and family life", 346.
} 
as we can see from these and other photographs that they were part of visual propaganda campaigns, but how were children encouraged to participate in the "national effort" and to what extent did they internalize the values of the "war culture"?

\section{SCHOOLS AT WAR}

Many of the opportunities for children and young people to participate in the war effort were organized through schools and school log books enable the historian to get a glimpse of how the war intruded on their lives although the level of detail varies. At Clifton Road Boys School there is no evidence in the entries for 1914 and 1915 that the war was actually happening and the log book records the 'normal' rhythm of school life. In 1916 there are four entries: "Spent $£ 2$ in providing \& sending eight parcels to our "Old Boys" now at the Front"; "Four more parcels sent to "Old Boys" at Front"; "Mr Whatmore leaves for military service"; and

Dispatched 22 more parcels containing scarf \& cigarettes or socks and mittens [...] to old boys (soldiers \&sailors) who have left this school since I took charge in July 1910. Great enthusiasm among present pupils \& teachers. ${ }^{52}$

The following year the death in action of Whatmore is recorded. "Boys and Teachers" also sent gifts of "Fruits, Eggs, Cocoa, Jam, Cakes, Cigarettes, etc. etc., to the wounded soldiers in the Queen's Hospital, Birmingham". The entries for 1918 are dominated by references to male teachers being absent at Medical Board examinations at the city's Curzon Hall. The School closed early in May 1918 "on account of "maroons"” and in September boys visited "the Exhibition of Trades of wounded \& recovered soldiers held at Town Hall". Clifton Road, as with other local authority schools, was closed on the $11^{\text {th }}$ and $12^{\text {th }}$ of November due to the "cessation of hostilities". ${ }^{53}$

\footnotetext{
${ }^{52}$ Library of Birmingham, S50/2/1, Clifton Road Boys School Log Book, 12 August.1916; 17 May 1916; 26 July 1916; 27 December 1916.

${ }^{53}$ Library of Birmingham, S50/2/1, Clifton Road Boys School Log Book, 11 October1917; 19 October1917; 11 March 1918; 9 May 1918; 16 May 1918; 17 May 1918; 12 September 1918.
} 
Such brief and intermittent references to the war contrasts sharply with the entries for Dartmouth Street Boys School. The first reference to the war was on the $24^{\text {th }}$ August 1914 and is cryptic, "School reopened this morning. All the staff present. War Conditions", and, presumably added later, in the margin is written, "The Great War". ${ }^{54}$ This was followed, as already noted, by a series of references to local financial hardship and a sharp increase in the number of children needing free breakfasts. Between 1914 and 1919 the Head Teacher gave seven series of lectures to the boys. The lectures were accompanied by the reading of "Patriotic Poems". Over seventy lectures were given and ranged over such topics as "Patriotism (Empire)", "Colonial Gifts to the Motherland", the South African Rebellion, the Great Battle of Ypres, German Atrocities, Gas Attacks in the West, the Military Camp at Salonika, Compulsory Service, “The Waste of War (Young Lives)", German Propaganda, Education after the War, Entry of America into the War, "The Great Re-Union of the Anglo-Saxon Race", the sinking of hospital ships, London air raids, the Russian Revolution, Allied Air Development, Capture of Bagdad, Final Defeat of Submarine War, "The Great Lessons - Self-Forgetfulness and Unity”, "Abdication of Kaiser. Failure of "Might is Right"” and "Hopes of Mankind in the League of Nations". Not surprisingly, pupils were praised by school inspectors in 1915 for their good knowledge of the history and geography of the war. ${ }^{55}$ Letters from "Old Boys at the Front" were read to the school and were "productive of much good work". ${ }^{56}$ The School was the site both of celebration and mourning. Cheers were given by the boys at a special assembly on the announcement that Private Arthur Vickers, a former pupil, was awarded the Victoria Cross and a half day's holiday was given when he visited the school. Press reports and photographs of the event were collected and displayed.$^{57}$ In 1916 a short service was held for the whole school in memory of the naval "Heroes lost in the North Sea battles" and in 1917 the Head Teacher recorded,

\footnotetext{
${ }^{54}$ Library of Birmingham, S56/2/2, Dartmouth Street Boys School Log Book, 24 August 1914.

${ }^{55}$ Library of Birmingham, S56/2/2, Dartmouth Street Boys School Log Book, 14-16 June 1915.

${ }^{56}$ Library of Birmingham, S56/2/2, Dartmouth Street Boys School Log Book, 4 February 1916.

${ }^{57}$ Library of Birmingham, S56/2/2, Dartmouth Street Boys School Log Book, 19 November 1915.
} 
[...] it has been my painful duty to announce to the school the death in action of a number of old scholars: where possible recent letters have been read, and photographs of the school's dead heroes have been placed in the corridor. ${ }^{58}$

The Head Teacher recorded his praise for the efforts of the boys in raising money for the war effort and listed the various funds:

Hospitals, Belgian Relief, Serbian Relief, Soldiers Huts (YMCA \& Church Army), Kitchener and Lord Robert Memorials, Jack Cornwall Memorial Hospital, Barnardo Homes Empire Day, Overseas Clubs' Xmas Gifts, Old Scholar's (Soldiers Blinded) Gifts, Injured Horses..$^{59}$

Between August 1914 and June 1919 they collected over $£ 50$ for various war charities, a significant amount of fundraising which must have represented a considerable drain on most families' budgets. The end of the war was marked by the boys singing the National Anthem and giving "cheers for the flag". On Armistice Day 1919 a special assembly was organized that included "Hymns, Songs and suitable music", and an address by the Head Teacher "on the memory of the glorious Dead". Silent remembrance was observed and "Special Lessons on the Celebration and on the League of Nations were given to all classes, ending with the singing of the National Anthem".

There was certainly "great enthusiasm" amongst the pupils of Clifton Road but the Dartmouth Street Log Book reads almost as a record of memorialisation. Did children internalize the values associated with this culture? The school log books, like most education records, are silent on the question as the voices of children are absent. However, a report accidentally found while looking for images in the Birmingham Illustrated Weekly Mercury newspaper gives some clues. On the $13^{\text {th }}$ November 1915 the newspaper ran a children's competition on the theme "What can the Little Ones do in War Time?", and half a crown was offered for the best letter. First prize was awarded to Irene Harrison age 13 from 145 Lady-

\footnotetext{
${ }^{58}$ Library of Birmingham, S56/2/2, Dartmouth Street Boys School Log Book, 9 June1916; 28 September 1917.

${ }^{59}$ Library of Birmingham, S56/2/2, Dartmouth Street Boys School Log Book, 14 December 1917.
} 
pool Road, Sparkbrook, one of six children of a widowed mother. Her winning entry was published on $20^{\text {th }}$ November:

Denial is a great sacrifice, and it would bring a smile to many a soldier's face if he had a cigarette that was bought with our pennies that were saved each week instead of being squandered at the sweet shops. "Tommy" would treasure a scarf, a pair of gloves, knitted pair of socks or a helmet; he would think more of them if bought and knitted with our small hands, for every soldier has not a sweetheart, wife, or mother; lots of them, given the title of "The Lonely Soldier", never receive parcels from relations like their chums do when away from their home; the simple reason is because they have no friends or relations. Would not it be nice to feel that we have got a friend who is a big red-faced soldier? ${ }^{60}$

A further selection of letters was published on $27^{\text {th }}$ November, and like Irene the authors advocated duty and sacrifice. Stanley Eld, age 13, living at 69 Somerset Road, considered it to be:

absolutely necessary that we should be well equipped to take the fallen's places either in business, professional, or commercial careers $[\ldots]$ by just studying hard and keeping fit I am convinced we shall be doing our bit.

Mary Nicholls, age 10, of 147 Vicarage Road, Aston, advocated buying British and knitting for soldiers:

One of the first things I think little children should do is to make up their minds that they will not purchase anything made by Germans or Austrians, for by doing so they are helping the enemy. At the Vicarage-road School girls like myself are taking home wool to knit socks to send to our soldiers.

Harold Collins, age 13, of 48 Newport Road, Balsall Heath, suggested that "Some boys interested in wood-work could make picture frames and brackets which they could sell and give the proceeds to war funds",

${ }^{60}$ The Birmingham Weekly Mercury, 20 November 1915, 6. 
whilst Albert J. Harris, of 31 Eton Road, Sparkbrook, thought girls had a particular role, presumably influenced by some of the recruiting posters which appeared at the time, he thought that girls should "help the recruiting sergeants by trying to persuade the "slackers" to enlist voluntarily while they have the chance". Several of the child writers focused on Belgian refugees, Leslie A. Harris, age 12, of 141 Ladypool Road, Sparkbrook, argued that:

Most boys and girls could afford a halfpenny or a penny every week to help this excellent cause... When one thinks about it one realises that the Belgians deserve it, because if it had not been for their bravery and courage the Germans may have been pillaging England the same as they did in Belgium. ${ }^{61}$

\section{CHILDREN DISPLACED BY WAR}

The reference to Belgium Refugees offers a link to our two final photographs (figures 9 and 10). Published on New Year's Day 1900 Ellen Key's Barnetsårhundrade (later published in English as The Century of the Child) presented the wellbeing and universal rights of the child as the defining mission of the twentieth century. ${ }^{62}$ Writing almost a century later, John Berger commented that "Ours is the century of enforced travel [...] the century of disappearances. The century of people helplessly seeing others, who were close to them, disappear over the horizon". ${ }^{63}$ The two final photographs act as a bridge between these two writers as they are both of children displaced by war and taken for fundraising and promotional purposes. In neither image do the children look distressed and yet both groups of children were refugees who had been uprooted from all they knew and been displaced in history.

\footnotetext{
${ }^{61}$ TheBirmingham Weekly Mercury, 27 November 1915, 7.It is possible using the names and addresses of the letter writers to identify them and their schools through the city's Education Census Record Books. While it was possible to locate the schools, the log books are only available for one of the schools, Vicarage Road Girls School, and there is no mention of the competition, see Library of Birmingham, S124/2/2, Vicarage Road Girls School, 1897-1936.See also, The World War and Personal Expressions by Children: 150 German School Essays (1915), British Library www.bl.uk/world-warone/articles/childrens-experiences-of-world-war-one.

${ }^{62}$ Ellen Key, The Century of the Child (New York: G. P. Putnam, 1909).

${ }^{63}$ John Berger, Keeping a Rendezvous (London: Granta Books, 1992), 12.
} 


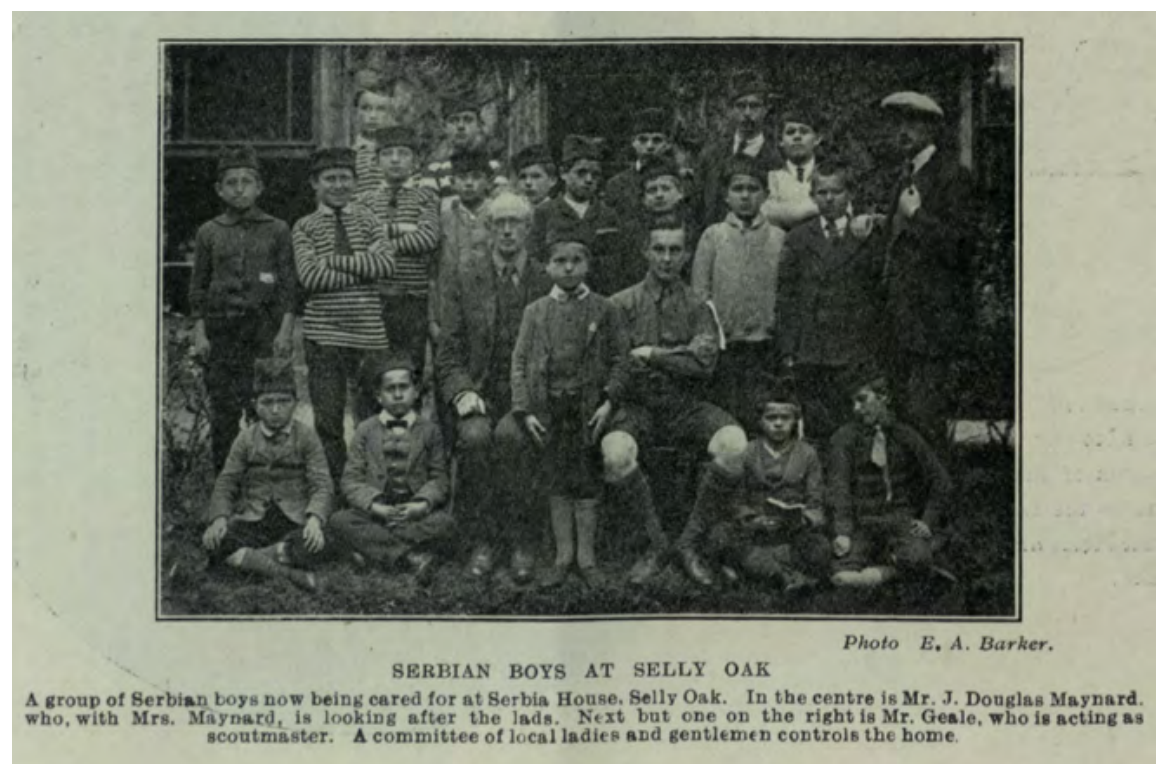

Figure 9: Serbian boys in Birmingham, Bournville Works Magazine, August 1916, p. 222. Reproduced with the permission of the Cadbury Archive, Mondelēz International.

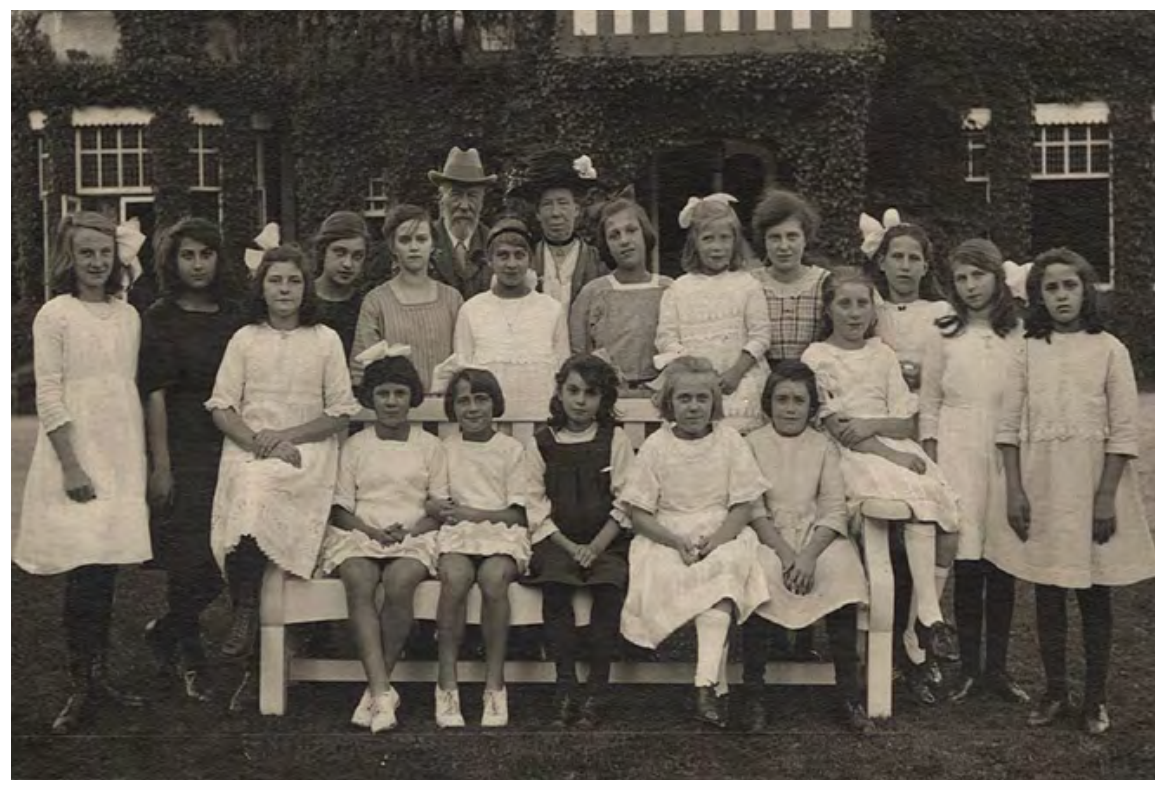

Figure 10: Girls from Vienna with George and Elizabeth Cadbury, 1921, Library of Birmingham MS 466/8/53. Reproduced with the permission of the Cadbury Archive, Mondelēz International. 
Brazier and Sanford devote a chapter of Birmingham and the Great War 1914-1919 to Belgian and Serbian Exiles. The Belgian refugee story is better known because of its scale, its association with the beginning of the war and its use in British anti-German propaganda. Birmingham was one of the cities which in 1916 exhibited in its art gallery Louis Raemaker's cartoon depictions of German war atrocities in Belgium and Raemaker had earlier visited the city in $1915 .{ }^{64}$ The Serbian refugee story is less well known. The caption under figure 9 tells us that the boys are from Serbia, that they are being cared for by J. Douglas Maynard and his wife Adelizaat Serbia House, Selly Oak, and that the home was controlled by a "a committee of local ladies and gentlemen".

The two adults in the photograph are identified as Maynard and "Mr [Alan] Geale, who is acting as scoutmaster". The image was reproduced both in the Weekly Mercury and the Bournville Works Magazine. The works in the magazine title refers to the Cadbury family's chocolate factory, which was located in the Birmingham suburb of Bournville. ${ }^{65}$

Brazier and Sandford only devote two pages to the Serbian refugees compared to ten pages on the Belgians in Birmingham. Nevertheless, they add details to what we can see in the photograph. 25 boys aged between 10 and 14 arrived in Selly Oak in early 1916 and many of them "were still suffering from the effects of exposure and semi-starvation" following the retreat across the Albanian mountains. While at Serbia House their education was funded by the Serbian Relief Fund, one of the war charities supported by the pupils at Dartmouth Street Boys School. The older boys "through the medium of scouting"” were trained in leadership responsibilities and passed and enforced hostel rules. The hostel was administered by local Quakers - Elizabeth Cadbury chaired the committee, W.A. Albright was treasurer. ${ }^{66}$ In addition, to this information there is an account in Elizabeth Cadbury's family journal letter of the boys arrival at the hostel on Saturday $20^{\text {th }}$ May 1916 with their Serbian schoolmaster

\footnotetext{
${ }^{64}$ The Birmingham Post, 29 November 1915 and 27 October 1916. For a discussion of Raemaker's cartoons and their impact, see Sue Malvern, Modern Art, Britain and the Great War (New Haven: Yale University Press, 2004).

${ }^{65}$ The Birmingham Weekly Mercury, 1 July 1916; Library of Birmingham, L66.53, Bournville Works Magazine, 1916.

${ }^{66}$ Brazier and Sanford, Birmingham and the Great War, 317-18.
} 
when they were met by a band of Birmingham Boy Scouts and "marched up to the house with flags flying" 67 The boys returned home in 1919.

The two photographs are linked both by place and people. On 29 October 1920, 18 girls from Vienna arrived in Bournville where they lived with local families for a year. Here we can see the girls with George and Elizabeth Cadbury who contributed 15 shillings weekly for the maintenance of each child. ${ }^{68}$ The Quaker paper The Friend reported their arrival describing them as

sweet-looking children of from 8 to 12 years of age [who] all appeared to be very happy as they trooped into the Infants' School, many of them carrying all their possessions in a small bundle on their backs. ${ }^{69}$

The article goes on to describe their efforts to learn English and the reaction of their hosts in Bournville, closing with the reminder to its readers that "tens of thousands of little children" in Austria "will probably suffer for life through the lack of food". The girls' return to Vienna on 2 September 1921 was similarly reported in The Friend; the article describes how the children and their foster parents clung to each other weeping and contrasted the appearance of the "healthy, plump looking" children, "well clothed and well cared for", with the "thin emaciated and badly clothed" children who had arrived a year earlier. ${ }^{70}$

The difference between these two groups of children was that the girls were the "children of enemies". They had escaped from a city of suffering following the Allied blockade. There is a further link between the two images. They are both a product of the international humanitarian relief movement; a movement which brought to Birmingham (amongst other cities) an exhibition of children's art in the early 1920s, including artwork from both Serbia and Vienna. The exhibition was aimed at raising money for child relief in Vienna, performed by the Save the Children Fund recently founded by Eglantyne Jebb and her sister Doorothy Buxton, and was accompanied by a series of publications written by Francesca Wilson, a former relief work-

\footnotetext{
${ }^{67}$ Library of Birmingham, MS 466/1/1/15/3/13.

${ }^{68}$ Library of Birmingham, L66.53, Bournville Works Magazine, November 1921, 283.

${ }^{69}$ The Friend, 19 November 1920, 743.

${ }^{70}$ The Friend, 16 September 1921, 613.
} 
er in Serbia who was working with the Quaker Mission in Vienna. ${ }^{71}$ The publications were illustrated with examples of the children's artwork, and in one of her pamphlets Wilson touched on the psychological dimension of the artwork and its reflection of the effect of war and its aftermath on the children. ${ }^{72}$ None of the children in either photograph look distressed and yet both groups of children had been displaced by war, uprooted from their home and separated from their history. Their stories physically and emotionally give real meaning to Jebb's observation that "Every war, just or unjust, is a war against the child". Jebb saw no distinction between the children of allies and enemies: "all children were innocent and deserved assistance". ${ }^{73}$ Wilson later wrote a biography of Jebb. ${ }^{74}$ Finally, refugee stories are also powerful reminders that the "local", as Doreen Massey has emphasized is always a product in part of "global forces". ${ }^{75}$

\section{CONCLUSION}

It is self-evident from the image led account presented above that "the logic of total war disrupted the routines, formalities, and procedures that had previously provided the rhythm of educational life" in Birmingham schools. ${ }^{76}$ Schools were sites of patriotism where children contributed to "war work" by collecting for charities and war savings and engaged in activities to honour and memorialize the sacrifice of adults. Nevertheless, schools still continued to function as sites of organised learning. Just as the rhythms of educational life in Birmingham were disrupted by the war so too were those associated with family life and home, Birmingham families endured economic and emotional hardships. However, Catherine Rollet has pointed to the difficulties associated particularly with trying to uncover the emotional experiences of children with fathers at the front and cautioned that "in the case of children, historians need to be

\footnotetext{
${ }^{71}$ Siân Roberts, "Exhibiting children at Risk: Child Art, International Exhibitions and Save the Children Fund, 1919-1923", Paedagogica Historica, 45, no. 1\&2 (2009): 171-90.

${ }^{72}$ See Siân Roberts, Place, Life Histories and the Politics of Relief: Episodes in the Life of Francesca Wilson, Humanitarian Educator Activist'. Unpublished PhD thesis, University of Birmingham 2010, chapter 2.

${ }^{73}$ Roberts, "Exhibiting children at Risk", 172.

${ }^{74}$ Francesca Wilson, Rebel Daughter of a Country House: The Life of Eglantyne Jebb, Founder of Save the Children Fund (London: George Allen and Unwin, 1967).

${ }^{75}$ Doreen Massey, "Places and their Pasts", History Workshop Journal, 39 (1995), 183.

${ }^{76}$ Stefan Goebel, "Schools”, in Winter and Robert (eds.) Capital Cities at War, 232.
} 
even more diffident". There is she argues "very little direct material, some drawings and school essays, letters, personal diaries written by the older children and then autobiographies — but these recreate experience of war after the event". ${ }^{77}$ This warning could also be employed when talking of the experiences of refugee children.

Children were used, whether knowingly or not, as instruments of adult persuasion and propaganda. This is clearly demonstrated by the images we have identified which were in circulation in local newspapers. Patriotic events employed children as key social actors and photographs were circulated which captured these moments. In these photographs we see the past but in the majority of cases the faces of the children remain unknown. Nevertheless, the photographs reveal the social world of which they are a part and we can witness their connections to the wider social narratives of both community and nation. The photographs we located and used did open up lines of enquiry and enabled connections to be made with other images, but also with written archives. It may be the case that these lines of enquiry and record linkages would have occurred anyway if we had not chosen to place the visual at the centre of our investigations, even so, the photographic evidence of children at war has taken our gaze beyond the institutional sites of school and home that are so often assessed by historians of childhood. As Kim Rasmussen observed, "places for children" are only seldom the same as "children's places". ${ }^{78}$ The photographs used in this paper, and many of the others found in the archive, point to the significance in children's lives of public spaces. These were spaces of performance and spectacle where children gathered to witness the mobilization and departure of men going to war. They were also spaces where the sounds and sights of childhood changed. They were spaces where children experienced both a "complex of representations" and the "circulation of representations", the effects of the one "always articulating into and re-working the other". ${ }^{79}$ Men in uniform, some wounded or mutilated, were ever present on the street. The street was a place of flag days and other campaigns to raise funds.

\footnotetext{
${ }^{77}$ Rollet, "The home and family life", 345.

${ }^{78}$ Kim Rasmussen, "Places For Children - Children's Places”, Childhood, 11 February 2004, 156-66.

${ }^{79}$ John Tagg, “The Discontinuous City: Picturing and the Discursive Field”, in Visual Culture: Images and interpretations, eds. Norman Bryson, Michael Ann Holly and Keith Moset (London: Wesleyan University Press, 1994), 85.
} 
Street advertising covered the walls and temporary hoardings of the city but the content and language was different. Patriotic symbolism and legal notices visually testified that the city was at war. Maroons became a feature of the city soundscape, and children were able to see and touch the new mechanical weapons of destruction. Cinemas showed images of war and patriotism, music halls interspersed comic turns with one act plays about the war. If children could did not see them, they would know of them through overheard adult conversations. The night, which before the war was turned into day through illumination, returned to semi-darkness because of fear of aerial attacks; attacks which brought the noise of war into public and private spaces. All these sensory experiences became strands in the fabric of children's identity in wartime Birmingham.

What was the legacy of experiences such as these? The social and psychological results of the "war to end all wars" was profound. It not only affected how people thought about the future, but also their view of the child as part of that future. John Thorne has pointed to the period after the "Grande Guerre" as being one of "cultural demobilisation", a turning away from the culture of war. ${ }^{80}$ The Declaration of the Rights of the Child drafted by Jebb and approved by the League of Nations in September 1923 was one element in this process. ${ }^{81}$ It was universal, without any distinction on the basis of nationality, "race", or religion. Children assumed "unprecedented importance" with the 1920s being hailed as the Children's Decade. ${ }^{82}$ The wellbeing of the body and the mind of the child became the focus of professional study. ${ }^{83}$ The extent to which these concerns were linked to the emotional impact of the culture of war on children rather than the product of idealism and humanitarianism in the face unprecedented loss of life and suffering remains unproven. Cabanes has recently cautioned about "overestimating the extent to which children's psychological wounds were actually taken into consideration in the wake of the Great War" and instead points

\footnotetext{
${ }^{80}$ John Horne, "Démobilisations culturelles après la Grande Guerre", in 14-18, Aujourd'hui, Today, Heute (Paris: Éditions Noésis, 1998), 45-53.

${ }^{81}$ See Edward Fuller, The Right of the Child. A Chapter in Social History (Boston: Beacon Press, 1951); Wilson, Rebel Daughter of a Country House.

${ }^{82}$ Alice Boardman Smuts, Science in the Service of Children 1893-1935 (New Haven: Yale University Press, 2006), 139.

${ }^{83}$ Boardman Smuts, Science in the Service of Children 1893-1935. See also John Stewart, Child Guidance in Britain, 1918-1955: The Dangerous Age of Childhood (London: Pickering \& Chatto, 2013).
} 
to the Second World War as marking the emergence of such concerns. However, he also points out that the history of the 1920s "remains significantly underdeveloped in contrast to the large amount of scholarly work devoted to the First World War and the 1930s". ${ }^{84}$

The photographs used in this paper animated our gaze, but as with all evidence there are problems with regard to use. Photography as Hans Belting has noted "is a medium between two gazes". What is captured in a photograph is a product of the gaze of the photographer which is then transferred "onto our gaze when we stand before the finished picture". ${ }^{85}$ Meaning therefore cannot be understood without taking into account the context and issues which come into play at the time the photograph was taken. Similarly, if the context in which we view these images changes so too can the meaning we take from them and also their emotional impact. The meaning of a photograph like that of any other entity is "inevitably subject to cultural definition" ${ }^{86}$ Therefore, it is necessary in the case of these images, as with those of Charles Lansiaux, to take into account the effect of viewing them through the lens of both commemoration and academic engagement.

This paper began with a discussion of an exhibition of documentary photography produced during a period of conflict which fundamentally changed the world. The Tate in 2007 curated a survey exhibition of photographing Britain. In the accompanying exhibition book the curators Val Williams and Susan Bright wrote:

When an anonymous photographer documented a group of maimed servicemen before and after the fitting of new limbs, the importance of photography at the home front emerged as immense. The sense of nationhood, which had been so prominent in the golden summer that preceded it, was challenged and damaged. Like photography, it would never be the same again. ${ }^{87}$

\footnotetext{
${ }^{84}$ Bruno Cabanes, The Great War and the Origins of Humanitarianism 1918-1924 (Cambridge: Cambridge University Press, 2014), 8.

${ }^{85}$ Hans Belting, An Anthropology of Images (Princeton: Princeton University Press, 2011), 154.

${ }^{86}$ Allan Sekula, Photography against the Grain. Essays and Photo Works, 1973-1983 (Halifax, Nova Scotia: Nova Scotia College of Art and Design, 1984), 3.

${ }^{87}$ Val Williams and Susan Bright, How We Are. Photographing Britain from the 1840s to the present (London: Tate Publishing, 2007), 65.
} 


\section{Notes on contributors}

IAN GROSVENOR is professor of Urban Educational History at the University of Birmingham, England and has responsibility for City and Cultural Liaison. Books include, Assimilating Identities. Racism and Education in Post 1945 Britain (1997), Silences and Images. The Social History of the Classroom (1999) with Martin Lawn and Kate Rousmaniere, The School I'd Like (2003), School (2008) and The School I'd Revisited (2015) all with Catherine Burke, Materialities of Schooling (2005) with Martin Lawn, Children and Youth at Risk (2009) with Christine Mayer and Ingrid Lohmann, the Black Box of Schooling (2011) with Sjaak Braster and Maria del Mar del Pozo Andres and Making Education: Governance by Design (2018) with Lisa Rasmussen. He is Director of the Voices of War and Peace First World War Engagement Centre and is a Fellow of the Royal Historical Society.

SiÂn RoberTs is a lecturer in the Department of Education and Social Justice at the School of Education, University of Birmingham, England. Her research interests include educational humanitarian interventions by British Quaker women, refugee educationalists who arrived in the UK in the first half of the twentieth century, and educational interventions with children and young people in contexts of war or displacement. Siân has published a number of articles on these issues, and is also a member of the Executive Committee of the History of Education Society UK.

\section{REFERENCES}

Audoin-Rouzeau, Stephane. "Children and primary schools of France, 1914-18». En State, society and mobilization in Europe, during the First World War, editado por John Horne, 39-52. Cambridge: Cambridge University Press, 1997.

BaILey, Victor. Delinquency and citizenship: Reclaiming the young offender, 19141948. Oxford: Clarendon Press, 1987.

Banks, Marcus. «Visual Methods in Social Research». Social Research Update 11 (1995).

BECKER, Howard. «Do photographs tell the truth?». En Qualitative and Quantitative Methods in Evaluation Research, editado por Thomas Cook and Charles Reichardt.London: Sage, 1979.

BeLting, Hans. An Anthropology of Images. Princeton: Princeton University Press, 2011. 
Berger, John. Keeping a Rendezvous. London: Granta Books, 1992.

Boardman Smuts, Alice. Science in the Service of Children 1893-1935. New Haven: Yale University Press, 2006.

Bourke, Joanna. Dismembering the Male. Men's Bodies, Britain and the Great War. London: Reaktion Books, 1996.

BrazIER, Reginald H. and Ernest SANFORD. Birmingham and the Great War 19141919. Birmingham: Cornish Brothers, 1921.

BRITISH Library. «The World War and Personal Expressions by Children: 150 German School Essays». 1915. www.bl.uk/world-war-one/articles/childrens-experiences-of-world-war-one.

CaBanes, Bruno. The Great War and the Origins of Humanitarianism 1918-1924. Cambridge: Cambridge University Press, 2014.

CAllister, Sandy. «Picturing Loss: Family, Photographs and the Great War». The Round Table. The Commonwealth Journal of International Affairs 96, no. 393 (2007): 663-678.

Clarke, Graham. The Photograph. Oxford: Oxford University Press, 1997.

DAs, Santanu. Touch and Intimacy in First World War Literature. Cambridge: Cambridge University Press, 2005.

EDWARDS, Elizabeth. "Little Theatres of Self". Thinking about the Social». En We are the People. Postcards from the Collection of Tom, editado por James Fenton, Elizabeth Edwards and Tom Phillips, 29-31. London: National Portrait Gallery, 2004.

EDWARDS, Elizabeth. «Entangled Documents: Visualised Histories». En Susan Meiselas: In History, editado por Kristen Lubben, 330-341. Gottingen: Steidl, 2008.

Fuller, Edward. The Right of the Child. A Chapter in Social History. Boston: Beacon Press, 1951.

Goebel, Stefan. «Schools».En Capital Cities at War. Paris, London, Berlin 19141919. Volume 2: A Cultural History, editado por Jay Winter and Jean Louis Robert, 188-235. Cambridge: Cambridge University Press, 2007.

Grosvenor, Ian and Kate Rousmaniere. «El uso de materiales visuales en la investigación histórico-educativa». Revista Mexicana de Historia de la Educación IV, no. 8 (2016): 231-53.

Grosvenor, Ian. «On Visualising Past Classrooms». En Silences and Images. The Social History of the Classroom, editado por Ian Grosvenor, Martin Lawn and Kate Rousmaniere, 83-104. New York: Peter Lang, 1999.

Horne, John. "Démobilisations culturelles après la Grande Guerre». En 14-18, Aujourd'hui, Today, Heute, 45-53. Paris: Éditions Noésis, 1998.

Jordanova, Ludmilla. "Approaching Visual Methodologies». En Research Methods for History, editado por Simon Gunn and Lucy Faire, 30-47. Edinburgh: Edinburgh University Press, 2011. 
Jordanova, Ludmilla. The Look of the Past. Visual and Material Evidence in Historical Practice. Cambridge: Cambridge University Press, 2012.

Kennedy, Rosie. The Children's War: Britain, 1914-1918. Basingstoke: Palgrave Macmillan, 2014.

Key, Ellen. The Century of the Child. New York: G. P. Putnam, 1909.

Linkman, Audry and Caroline Warhurst. Family Albums. Manchester: Manchester Studies, 1982.

Malvern, Sue. Modern Art, Britain and the Great War. New Haven: Yale University Press, 2004.

Massey, Doreen. «Places and their Pasts». History Workshop Journal 39 (1995): 182-192.

Metteau, Marie-Brigitte (ed.). Paris 14-18, la guerre au quotidian. Photographies de Charles Lansiaux. Paris: Bibliotheques de la Ville de Paris, 2014.

Moeller, Susan. Shooting War: Photography and the American Experience of Combat. New York: Basic Books, 1990.

Newbury, Darren. Defiant Images: Photography and Apartheid South Africa. Pretoria: University of South Africa Press, 2009.

Rasmussen, Kim. «Places For Children - Children's Places». Childhood 11 February (2004): 156-66.

RoBERTs, Siân. «Exhibiting children at Risk: Child Art, International Exhibitions and Save the Children Fund, 1919-1923». Paedagogica Historica 45, no. 1-2 (2009): 171-90.

Roberts, Siân. "Place, Life Histories and the Politics of Relief: Episodes in the Life of Francesca Wilson, Humanitarian Educator Activist'». Unpublished PhD thesis, University of Birmingham, 2010.

RoBerts, Siân. Birmingham: Remembering 1914-18. Stroud: The History Press, 2014.

Rollet, Catherine. "The home and family life». En Capital Cities at War. Paris, London, Berlin 1914-1919. Volume 2: A Cultural History, editado por Jay Winter and Jean Louis Robert, 315-354. Cambridge: Cambridge University Press, 2007.

Roper, Michael. The Secret Battle. Emotional Survival in the Great War. Manchester: Manchester University Press, 2009.

ScotT, John. A Matter of Record: Documentary Sources in Social Research. London: Polity, 1990.

Sekula, Allan. Photography against the Grain. Essays and Photo Works, 19731983. Halifax, Nova Scotia: Nova Scotia College of Art and Design, 1984.

Siegel, Mona L. The Moral Disarmament of France. Education, Pacifism and Patriotism, 1914-1940. Cambridge: Cambridge University Press, 2004.

Stewart, John. Child Guidance in Britain, 1918-1955: The Dangerous Age of Childhood. London: Pickering \& Chatto, 2013. 
TAGG, John. «The Discontinuous City: Picturing and the Discursive Field». En Visual Culture: Images and interpretations, editado por Norman Bryson, Michael Ann Holly and Keith Moset, 83-103. London: Wesleyan University Press, 1994.

Tinkler, Penny. Using Photographs in Social and Historical Research. London: Sage, 2013.

White, Jerry. Zeppelin Nights. London in the First World War. London: Bodley Head, 2014.

Williams, Val and Susan BRIGHT. How We Are. Photographing Britain from the 1840s to the present. London: Tate Publishing, 2007.

WiLson, Francesca. Rebel Daughter of a Country House: The Life of Eglantyne Jebb, Founder of Save the Children Fund. London: George Allen and Unwin, 1967. 